\title{
Mathematics and Accounting in the Andes Before and After the Spanish Conquest
}

\section{Citation}

Urton, Gary. 2012. Mathematics and Accounting in the Andes Before and After the Spanish Conquest. In Alternative Forms of Knowing (in) Mathematics, ed. Swapna Mukhopadhyay and Wolff-Michael Roth, 17-32. Rotterdam: Sense Publishers.

\section{Published Version}

doi:10.1007/978-94-6091-921-3_2

\section{Permanent link}

http://nrs.harvard.edu/urn-3:HUL.InstRepos:33702051

\section{Terms of Use}

This article was downloaded from Harvard University's DASH repository, and is made available under the terms and conditions applicable to Open Access Policy Articles, as set forth at http:// nrs.harvard.edu/urn-3:HUL.InstRepos:dash.current.terms-of-use\#OAP

\section{Share Your Story}

The Harvard community has made this article openly available.

Please share how this access benefits you. Submit a story.

\section{Accessibility}




\section{GARY URTON}

\section{MATHEMATICS AND ACCOUNTING IN THE ANDES BEFORE AND AFTER THE SPANISH CONQUEST}

In an article entitled "Western mathematics: The secret weapon of cultural imperialism," Bishop (1990) argues that Western European colonizing societies of the 15 th to 19 th centuries were especially effective in imposing on subordinate populations the values of rationalism and "objectivism" - defined as a way of conceiving of the world as composed of discrete objects that could be abstracted from their contexts - primarily through "mathematico-technological cultural force" embedded in institutions relating to accounting, trade, administration, and education (Bishop, 1990). Thus,

mathematics with its clear rationalism, and cold logic, its precision, its socalled 'objective' facts (seemingly culture and value free), its lack of human frailty, its power to predict and to control, its encouragement to challenge and to question, and its thrust towards yet more secure knowledge, was a most powerful weapon indeed. (p. 59)

The question to be addressed in this article is whether or not Western societies were unique in the use of mathematics, especially when employed in state accounting, as what Bishop terms a "weapon" of statecraft. A wealth of literature produced by critical accounting historians over the past several decades has elucidated the role of accounting as a technology of and a rationale for governance in state societies. Accounting and its specialized notational techniques are some of the principal instruments employed by states in their attempts to control and manage subjects. It is suggested that

[r]ather than two independent entities, accounting and the state can be viewed as interdependent and mutually supportive sets of practices, whose linkages and boundaries were constructed at least in their early stages out of concerns to elaborate the art of statecraft. (Miller, 1990, p. 332)

In this chapter I examine the policies and procedures of political arithmetic as employed in Western Europe in the early Renaissance period and in the contemporary, Inka Empire of Pre-Columbian South America. I argue that state accounting, as realized in the practices of alphanumeric, double-entry bookkeeping in Europe and in khipu (knotted-string) record-keeping in the Inka empire constituted highly effective strategies for the exercise of social control in the two settings. In addition 
to examining pre-conquest mathematical practices in the two separate settings, I consider the encounter between Spanish written (alphanumeric) record-keeping practices and Inka knotted-string record keeping following the European invasion and conquest of the Inka empire, in the sixteenth century. I begin with a brief overview of the rise of double-entry bookkeeping and the use of Hindu-Arabic numerals in accounting systems that emerged in the early Renaissance mercantile states of Western Europe.

\section{ACCOUNTING AND NUMERATION IN EUROPEAN DOUBLE-ENTRY BOOKKEEPING}

Two almost simultaneous developments in European mathematics and commercialism during the fourteenth-fifteenth centuries are critical to the picture of accounting and recordkeeping practices of Spanish colonial administrators in the sixteenth century. These developments were the invention of double-entry bookkeeping and the replacement of Roman numerals by Hindu-Arabic numerals. The earliest evidence for double-entry bookkeeping dates from the 13th century when the method was put to use by merchants in northern Italy. The first extended explanation of double-entry bookkeeping appeared in a treatise on arithmetic and mathematics written by the Franciscan monk Frater Lucas Pacioli in 1494. The invention and implementation of double entry went hand-in-hand with the replacement of Roman numerals by Hindu-Arabic numerals, which had been introduced into Western Europe almost five hundred years before their eventual acceptance into accounting practice, in the 15th century.

The cities of northern Italy that were the centers of commercial activities from the 14th to the 16th centuries also became centers of learning in arithmetic and mathematics. It was in these cities - Venice, Bologna, Milan - that Hindu-Arabic numerals were first linked with double entry to form the basis of modern accounting science. It was here as well that abacus or "reckoning" schools grew up that were patronized by the sons and apprentices of merchants throughout Europe. The masters of those schools, the maestri d'abbaco, taught the new arithmetic, or arte dela mercadanta, "the mercantile art" (Swetz, 1989). It was in northern Italy as well where, a couple of decades prior to the publication of Pacioli's exposition of double-entry bookkeeping, the first arithmetic textbook, the so-called Treviso Arithmetic, was published in 1478. While not discussing the double-entry method itself, the Treviso Arithmetic proclaimed itself from the opening passage as intended for study by those with an interest in commercial pursuits. Double-entry bookkeeping employing Hindu-Arabic numerals spread throughout Western Europe in the century or so leading up to Spanish adventures in the New World.

From virtually the earliest years following the invasion of the Andes, European administrators - toting accounting ledgers filled with columns of Hindu-Arabic numerals and alphabetically written words and organized in complex formats came into contact with Inka administrative officials wielding bundles of colorful knotted cords. These local administrators - known as khipukamayuqs "knotkeepers/makers/organizers" - were, oddly enough, speaking the language (in 


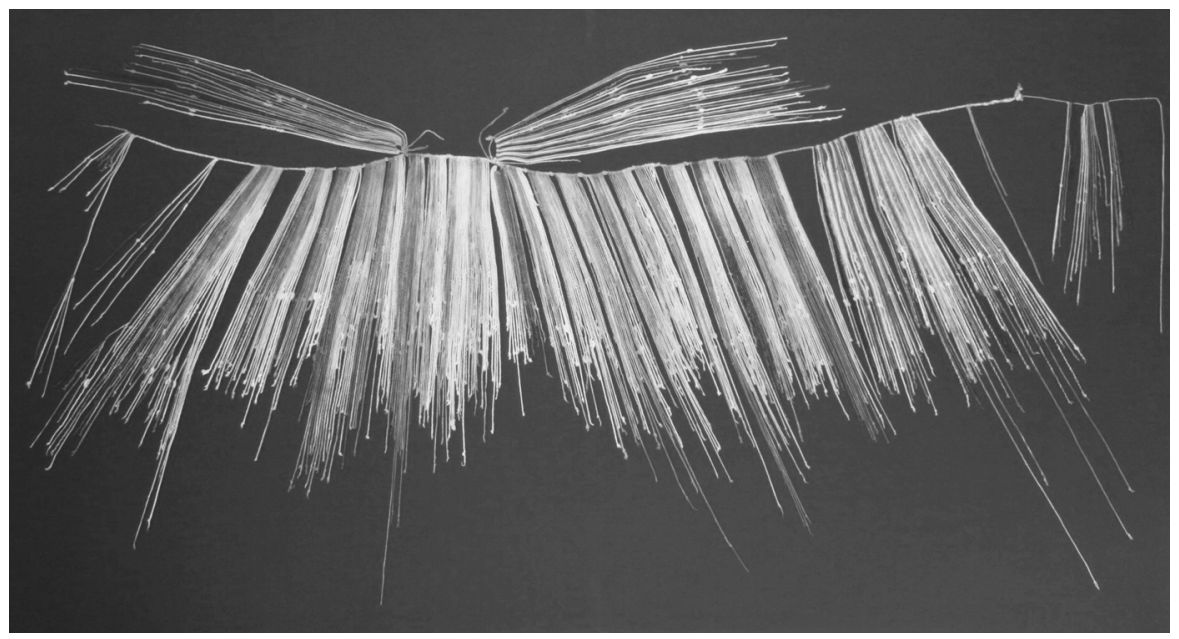

Figure 5.1. Khipu (Museum for World Culture, Göteborg, Sweden; \#1931.37.0001

Quechua) of decimal numeration and practicing what may have looked for all the world, to any Spaniard trained by the reckoning masters of northern Italy, like double-entry bookkeeping.

\section{THE KHIPU AND ITS METHODS OF INFORMATION REGISTRY}

Khipus are knotted-string devices made of spun and plied cotton or camelid fibers (Figure 5.1). ${ }^{1}$ The colors displayed in khipus are the result of the natural colors of cotton or camelid fibers or of the dyeing of these materials with natural dyes. The "backbone" of a khipu is the so-called primary cord - usually around $0.5 \mathrm{~cm}$ in diameter - to which are attached a variable number of thinner strings, called pendant cords. Khipus contain from as few as one up to as many as 1,500 pendants (the average of some 420 samples studied by the Harvard Khipu Database project is 84 cords). Top cords are pendant-like strings that leave the primary cord opposite the pendants, often after being passed through the attachments of a group of pendant strings. Top cords frequently contain the sum of values knotted on the set of pendant cords to which they are attached. About one-quarter of all pendant cords have second-order cords attached to them; these are called subsidiaries. Subsidiaries may themselves bear subsidiaries, and there are examples of khipus that contain up to six levels of subsidiaries, making the khipu a highly efficient device for the display of hierarchically organized information. ${ }^{2}$

The majority of khipus have knots tied into their pendant, subsidiary and top strings. The most common knots are of three different types, which are usually tied in clusters at different levels in a decimal place system of numerical registry (Figure 5.2). ${ }^{3}$ The most thorough treatment to date of the numerical, arithmetic, and mathematical properties of the khipus is Mathematics of the Incas: Code of the 
URTON

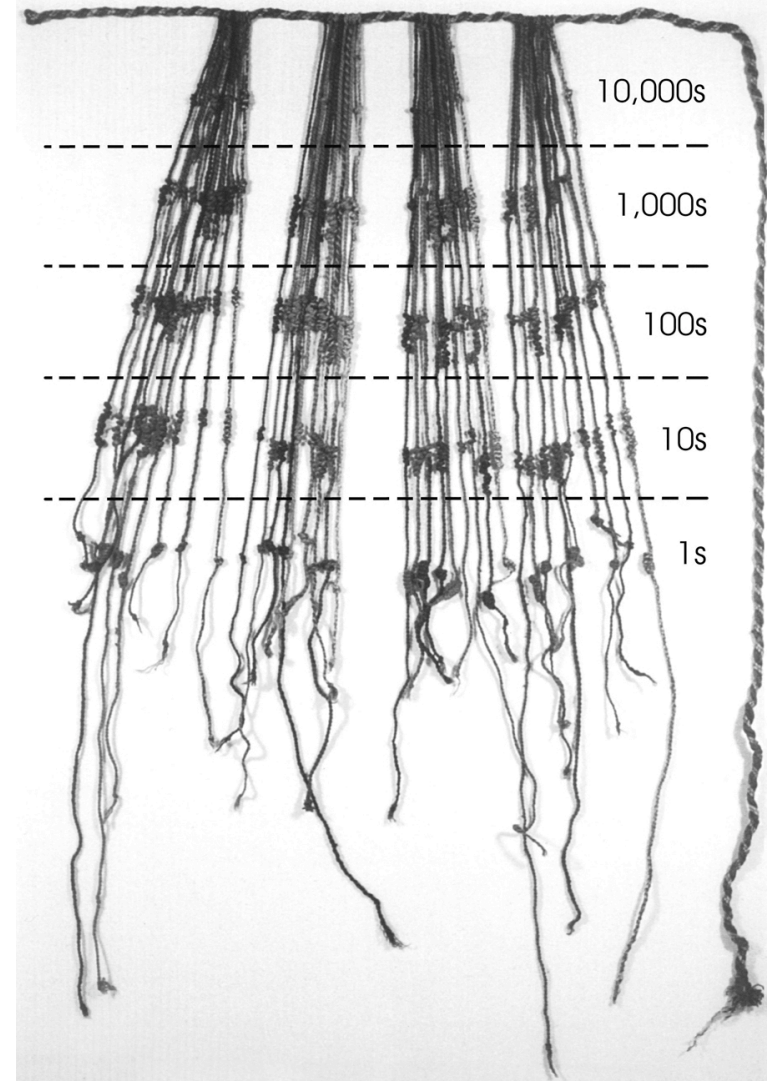

Figure 5.2. Clustering of knots on a khipu in decimal hierarchy

Quipus (Ascher \& Ascher, 1997). The Aschers have shown that the arithmetic and mathematical operations used by Inka accountants included, at a minimum, addition, subtraction, multiplication, and division; division into unequal fractional parts and into proportional parts; and multiplication of integers by fractions.

What kinds of information were registered on the khipus? In addressing this question, it is important to stress that - although we are able to interpret the quantitative data recorded in knots on the khipus - we are not yet able to read the accompanying nominative labels, which appear to have been encoded in the colors, twist, and other structural features of the cords. The latter would, were we able to read them, presumably inform us as to the identities of the items that were being enumerated by the knots. Thus, in discussing the identities of objects accounted for in the khipus, we are forced to rely on the Spanish documents from the early years following the European invasion.

According to the Spanish accounts, records were kept of censuses, tribute assessed and performed, goods stored in the Inka storehouses, astronomical peri- 
odicities and calendrical calculations, royal genealogies, or historical events. ${ }^{4}$ The overriding interest in the recording, manipulation, and eventual archiving of quantitative data in the khipus was the attempt to control subject peoples throughout the empire. This meant to be able to enumerate, classify, and retain records on each subject group. The most immediate use to which this information was put was in the implementation of the labor-based system of tribute. Tribute in the Inka state took the form of a labor tax, which was levied on all married, able-bodied men (and some chroniclers say women as well) between the ages of 18 and 50. In its conception and application to society, Inka mathematics appears to have taken a form remarkably like the political arithmetic of seventeenth-century Europeans. In sum, the decimal place system of recording values - including zero - of the Inka knotted-cords was as precise and complex a system of recording quantitative data as the written Hindu-Arabic numeral-based recording system of Europeans at the time of the conquest, although the records of the former were not as rapidly produced, nor as easily changeable, as those of the latter.

Accounting has long been one of the principal institutions and administrative practices involved in maintaining and legitimizing the status quo in western European nation-states. Can this be said of khipu accounting in the pre-Hispanic Andes as well? We gain a perspective on this question by looking at two accounts of how censuses were carried out in the Inka state. As in other ancient societies, census taking was a vital practice in the Inka strategy of population control, as well as serving as the basis for the assessment and eventual assignment of laborers in the mit'a (taxation by labor) system (Julien, 1988; Murra, 1982). The first account of census taking is from a famed mid-sixteenth century soldier and traveler:

...the nobles in Cuzco told me that in olden times, in the time of the Inka kings, it was ordained of all the towns and provinces of Peru that the head men [señores principales] and their delegates should [record] every year the men and women who had died and those who had been born; they agreed to make this count for the payment of tribute, as well as in order to know the quantity of people available to go to war and the number that could remain for the defense of the town; they could know this easily because each province, at the end of the year, was ordered to put down in their quipos, in the count of its knots, all the people who had died that year in the province, and all those that had been born. (Cieza de León, 1967 [1551], p. 62, my translation).

Some forty years after Cieza wrote down the information cited above, Martín de Murúa gave an account of Inka census taking that varies somewhat from Cieza's understanding of this process and that contains interesting details concerning the actual procedures involved in local population counts.

They sent every five years quipucamayos [khipu-keepers], who are accountants and overseers, whom they call tucuyricuc. These came to the provinces as governors and visitors, each one to the province for which he was responsible and, upon arriving at the town he had all the people brought together, 


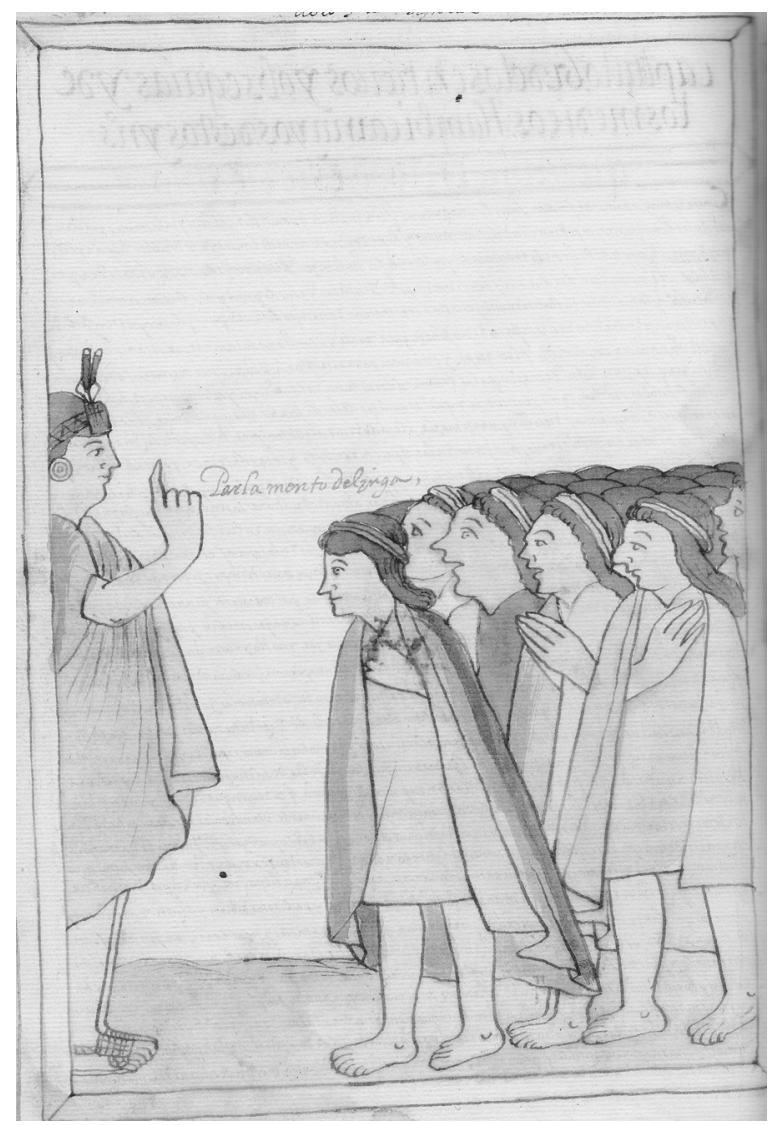

Figure 5.3. Conducting census count of men, by Age-Grade (Murúa, 2004, p. 114v)

from the decrepit old people to the newborn nursing babies, in a field outside town, or within the town, if there was a plaza large enough to accommodate all of them; the tucuyricuc organized them into ten rows ["streets"] for the men and another ten for the women. They were seated by ages, and in this way they proceeded [with the count]. (Murúa, 2004 [1590], p. 204, my translation)

Late sixteenth-century drawings of these male and female census accounting events from the chronicle of Martín de Murúa are shown in Figures 5.3 and 5.4.

In Inka census taking, people were ordered into public spaces to be counted and classified. Although resistance and evasion may have been common in such proceedings, from what the Spanish chroniclers and administrative officials tell us, Inka censuses were accomplished using non-coercive measures - that is, local people apparently were compliant with the claims of authority coming from local officials and state administrators. Thus, as much as an accounting tool, the census 


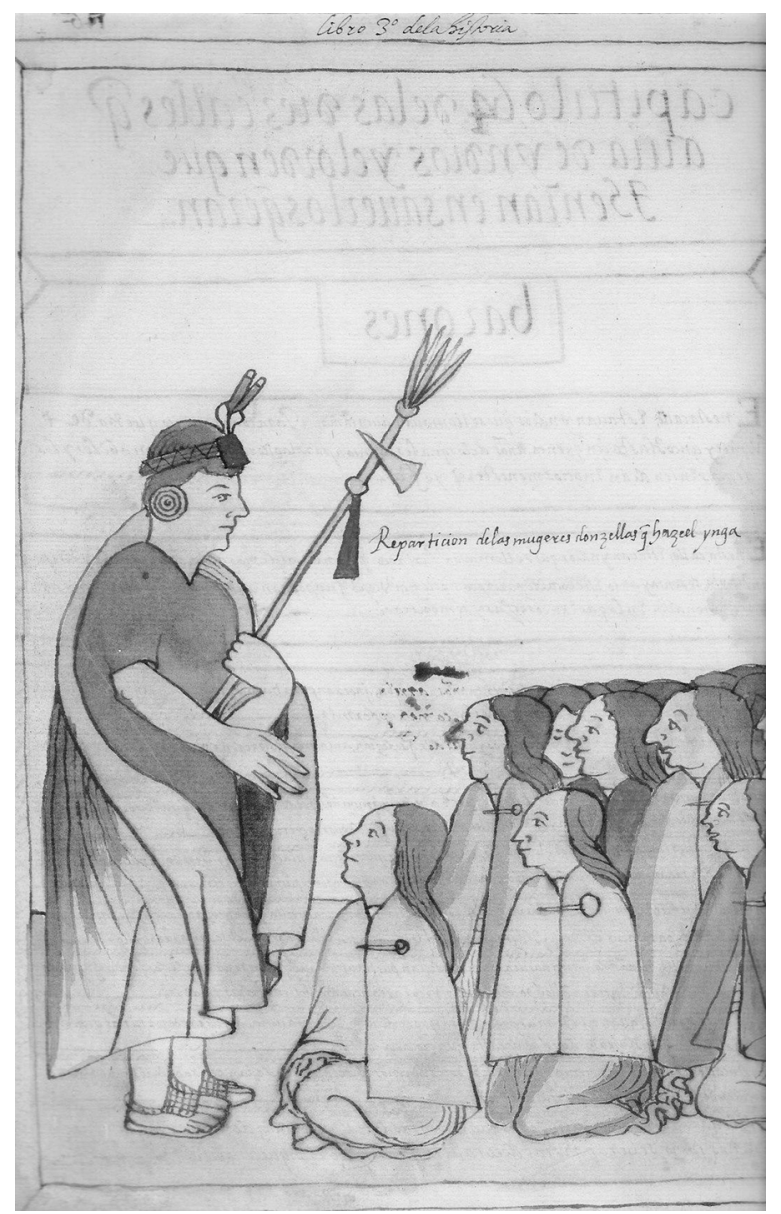

Figure 5.4. Conducting census count of women, by Age-Grade (Murúa, 2004, p. 116v)

khipu was an instrument for the performance and display of state authority and power within local communities. ${ }^{5}$ The census data collected by local recordkeepers were knotted into khipus, copies were made of each record, and the data were subsequently reported to higher-level accountants in regional and provincial administrative centers (see Urton \& Brezine, 2005). Two issues arise with respect to these procedures: one concerns the practice of making one or more copies of khipu records, the other concerns the training and education of state recordkeepers.

Whereas there are a number of references in the Spanish chronicles to khipu copies, the study of such copies in the corpus of extant khipus has proceeded slowly. Recent advances have come about, however, following the development of a searchable database - the Khipu Database (KDB). ${ }^{6}$ From searches of 420 or so 
samples included in the KDB, some 12-15 examples of copies of accounts have been identified. While referred to as duplicate, or "matching" khipus, we could also consider "pairs" of khipus to represent an original and a copy.

Copies (or matching) khipus occur in three different forms. First, there are examples in which the numerical values on a sequence of strings on one sample are repeated exactly on another khipu. In some samples of this type, we find that while the pair of khipus bears the same knot values, the colors of the strings may vary. The second type of matching khipus, which I have termed "close matches," involves instances in which two different samples contain not exactly matching sequences of numbers, but rather ones in which the values are similar (e.g., those of one sample varying a small amount from those on another sample). And, finally, we have examples in which a numerical sequence recorded on one cord section of a khipu are repeated exactly, or closely, on another section of cords of that same khipu.

Duplicate khipus may have been produced as a part of a system of "checks and balances." However, duplicates seem as well to possess most of the requisite elements of double-entry bookkeeping in which "all transactions were entered twice, once as a debit and once as a credit ... [T] he debit side pertained to debtors, while the credit side pertained to creditors" (Carruthers \& Espeland, 1991, p. 37). Close matches would be accounts in which the debits and credits sides of the ledger were not in balance. On pairs of khipus having identical numerical values on sequences of strings but in which string colors vary (Urton 2005, p. 150-1), color could have been used to signal the statuses of credits and debits in the matching accounts. ${ }^{7}$ In the Inka state, debit/credit accounting would have been employed primarily in relation to the levying of labor tribute on subject populations.

The principal information that we lack in order to be able to confirm whether or not duplicate khipus might have been produced and used as double-entry-like accounts are the identities of the objects recorded on the khipus. Since we still cannot read the code of the khipus, we are unable to determine whether paired accounts were simply copies made for the purposes of checks-and-balances or if they might represent a relationship between a debit for an item on one account and the credit for that same item on another account. Research into this matter is on-going. ${ }^{8}$

What can we say about the individuals who became khipu-keepers for the state? How were these individuals recruited and trained? What role did they play in exercising authority and maintaining social and political control in the Inka state? A late 16th-century chronicler provided the following account of a school that was set up in the Inka capital of Cusco for the training of khipu-keepers.

The Inca ... he set up in his house [palace] a school, in which there presided a wise old man, who was among the most discreet among the nobility, over four teachers who were put in charge of the students for different subjects and at different times. The first teacher taught the language of the Inca ... and upon gaining facility and the ability to speak and understand it, they entered under the instruction of the next [second] teacher who taught them to worship the idols and the sacred objects [huacas].... In the third year the next 
teacher entered and taught them, by use of quipus, the business of good government and authority, and the laws and the obedience they had to have for the Inca and his governors. . . . The fourth and last year, they learned from the other [fourth] teacher on the cords and quipus many histories and deeds of the past. (Murúa, 2001, p. 364, my translation)

The curriculum for these young administrators-in-training aimed at engendering loyalty and adherence to the values, policies and institutions of the Inka state. The khipu studies component of the administrative curriculum fulfilled the common objective of accounting education, which is producing "governable persons" who themselves would go on to serve as provincial administrators. The curriculum and examination promoted discipline and proper accounting practices in a way that rationalized institutional arrangements in the interest of the state and, ultimately, transformed the bodies and minds of the apprentice administrators.

The situation outlined above was not to last for long, however, as less than half a century after the school of administration was set up a cataclysmic event brought the school, not to mention the entire imperial infrastructure, crashing down; this event was the Spanish conquest.

\section{CONQUEST, COLONIZATION, AND THE CONFRONTATION BETWEEN KNOT- AND SCRIPT-BASED TEXTS}

The story of the conquest of the Inka empire by the Spaniards, which was undertaken by Francisco Pizarro and his small force of around 164 battle-hardened conquistadores, beginning in 1532, has been told too many times - in all its astonishing, entrancing and appalling details - for me to add much to the telling in the space available here (Hemming, 1970). The events of the conquest and the processes of colonization that are relevant for our discussion here are the following. The initial battle of conquest, which occurred in November 1532 in the Inka provincial center of Cajamarca, in the northern highlands of what is today Peru, resulted in the defeat of the Inka army and the capture and execution of Atahualpa, one of two contenders for succession to the Inka throne. Pizarro then led his small force southward arriving in the Inka capital city of Cuzco in 1534. The Spaniards and their native allies were soon forced to defend Cuzco against a rebellion led by the Spanish-installed puppet-king Manco Inca. This gave rise to a decades-long war of pacification of the rebels, which finally came to an end in 1572 with the execution of the then rebel leader, Tupac Amaru.

Three years prior to the capture and execution of Tupac Amaru, a new - the fifth - Viceroy of Peru Francisco de Toledo had arrived in Peru with a mandate to put down the rebellion and to transform the war- and disease-ravaged land of the former Inka empire into an orderly and productive colony for the benefit of the king of Spain Philip II. Viceroy Toledo instituted a set of reforms that were in some respects a continuation of certain of the processes of pacification, reorganization and transformation that had been on-going since the earliest days following the initial conquest. In other ways, Toledo's reforms represented something com- 
pletely new, different and profoundly transformative in their effects on Andean life-ways (Stern, 1993, p.51-79).

The end result of the Toledan reforms, the clear shape of which became manifest by the mid-to late 1570 s, included, most centrally, the following institutions: encomiendas - grants of groups of Indians to Spanish encomenderos "overseers" who were charged with the care and religious indoctrination of the natives and who, in exchange, had the right to direct native labor for their personal benefit but without the right (after the Toledan reforms) to levy tribute demands on them; corregimientos - territorial divisions for the management and control of civil affairs, including (theoretically) oversight of the encomenderos; reducciones - newlyformed towns that were laid out in grid-like ground plans to which the formerly dispersed natives were transferred for their surveillance, control and indoctrination; doctrinas - parish districts staffed by clergy who attended to the religious indoctrination of the natives within the reducciones and who received a portion of the tribute for their own maintenance; and mita - a form of labor tax based on the Inka-era mit'a, which supplemented what was, for Andeans, a new kind of tribute imposed on them by Toledo: specified quantities of agricultural produce, manufactured goods (textiles, sandals, blankets), and coinage.

The census was a critical institution for reorganizing Andean communities. Spanish censuses were carried out by administrative visitadores "visitors" who produced documents, known as a visitas, which were detailed enumerations of the population in the reducciones broken down (usually) into household groupings. Each household member was identified by name, age and - in the case of adult males - ayllu "social group" affiliation (Guevara-Gil \& Salomon, 1994; Urton, 2006). The visitadores were usually joined in their rounds by the kurakas "local lords" and often by the local khipukamayuqs. The khipu-keepers could supply historical, corroborating information on population figures and household composition (Loza, 1998). It is import to stress that participation by the native recordkeepers was not primarily for the benefit of the Spaniards, rather, it was to ensure that the natives would have their own, khipu-based accounts of the enumeration in the event - which seems always and everywhere to have come to pass - that disputes arose over the population count, the amount of tribute levied, or other administrative questions.

There are two contexts in which Andeans encountered Old World mathematical principles and practices: the manner of collecting information for the censuses, and the striking and circulation of coinage. These practices were closely linked to new forms of tribute, as well as to what was, for Andean peoples, a completely new form of communication: writing - that is, the inscribing of marks in ordered, linear arrangements on paper, parchment, or some other two-dimensional surface. Such a medium and associated recording technology were unprecedented in the Andean world.

Central to the Spanish attempt to establish an orderly colony in the former Inka territories, from the 1540 s through the 1570 s, was a program of enumerating the native population, investigating its form(s) of organization, and beginning to sketch out its history. One form that this process took was to call the khipu-keepers 
before colonial officials and have them read the contents of their cords (Loza, 1998). These recitations were made before a lengua "translator"; the Spanish words spoken by the translator were written down by a scribe. This activity resulted in the production of written transcriptions in Spanish alphanumeric script of the census data and other information previously jealously guarded by the khipukeepers in their cords.

Many of the khipu transcriptions discovered to date have been assembled in an important collection, entitled Textos Andinos (Pärssinen \& Kiviharju, 2004). The Spaniards were at least initially respectful of the khipus and their keepers, as the khipus were the primary sources of information on the basis of which Spanish officials began to erect the colonial administration. However, once the information was transferred from khipus to written texts, the locus of textual authority, legitimacy and power began to shift toward the written documents.

Whereas many native Andeans learned how to read and write alphabetic script and how to manipulate Hindu-Arabic number signs, only a handful of Spaniards appear to have achieved any degree of familiarity with the khipus (Pärssinen, 1992); it appears that no Spaniard became truly proficient at manipulating and interpreting the cords (Urton, 2003). What this meant was that, rather than contests over interpretations of information contained in the two sets of documents coming down to reciprocal readings of the two sets of texts, what emerged between the 1540 s and the 1570s were separate, contested readings by the keepers of the two different text types before a Spanish judge. As disputes intensified, and as more and more original data were recorded uniquely in the written documents, the khipu texts became both redundant and increasingly troublesome for the Spaniards (Platt, 2002). By the end of the tumultuous sixteenth century, khipus had been declared to be idolatrous objects - instruments of the devil - and were all but banned from official use. ${ }^{9}$

The circulation of coins is another area in which Andeans were confronted with a completely new and unfamiliar terrain of political relations, economic activity and shifting relations of authority over the course of the early colonial period. The first mint in South America was formally established in Lima in 1568, just 36 years after the events of Cajamarca. The royal decree that controlled the weights, fineness, and the fractional components of the coins to be struck in Lima were issued by Ferdinand and Isabella in 1479, which was amended by Charles V in 1537. The first coins struck in Lima bore a rendering of the Hapsburg coat of arms on the obverse and a cross with castles and lions on the quartered face on the reverse.

The two initial coin types were the real, a silver coin, and the gold escudo. Each of these coin types was broken down into subunits valued in relation to a general, unified standard of valuation known as the maravedí. The maravedi was used to coordinate values between different types of coins as determined by material differences and subdivisions of standard units (for example, the silver real $=34$ maravedis; the gold escudo $=350$ [from 1537-1566] or 400 [after 1566] maravedis). From this primary coordinating function, the maravedi served as a common denominator that permitted the interrelating of heterogeneous monetary values pertaining to gold and silver (Craig, 1989). 
URTON

From almost the earliest years following the conquest, Spanish officials in the countryside (the encomenderos) had been levying tribute in kind, which in some places included a demand for plates of silver and bars of gold, and translating the value of these items into Spanish currency values. Spanish officials regularly produced documents translating the quantities of items of tribute in kind into values in pesos ensayados (a unit of value in silver currency). This was the main context within which the kurakas "local lords" in communities would have begun to encounter translations of the use-value of objects, which they were familiar with in their local non-monetized economies, into exchange-values stated in terms of currency equivalents (Spalding, 1973). Furthermore, the Viceroy Francisco de Toledo introduced in the mid-1570s a new tribute system, which included not only produce and manufactured goods but also coins; the sum to be given yearly by each tributary was four-to-five pesos ensayados (that is, coinage in plata ensayada "assayed silver"). Tribute payers were designated as male heads of households between the ages of 18-50. The native chronicler Guaman Poma de Ayala drew several images of native people paying their tribute using what appears to be coinage bearing the quartered reverse face of the cuatro reales (Figure 5.5). ${ }^{10}$

People in the newly built reducciones were able to acquire coins to pay their tribute from forced work in the mines (a component of the Toledan tributary system), as well as from marketing and wage labor. The engagements with currency that resulted from these activities required people to begin to think about the different units of coinage, shifting equivalencies between coinage units, as well as to accommodate themselves to fluctuations in currency values in the periodic currency devaluations and the debasement of coinage that took place during the colonial period. The act of "devaluing" currency is a claim of authority on the part of some entity (e.g., state) over the exchange-value of the coinage one holds in one's own purse. One's subsequent use of that same coinage according to the newly announced rate of exchange represents compliance with the claim by the entity in question to control the value of one's currency. Although we have almost no data on the basis of which to consider how Andean peoples responded to such changes, these were some of the processes that were transpiring on the front lines of the confrontation between Old and New World mathematics entailing new and transformed notions of legitimacy, rationality, and authority in the early colonial Andes.

\section{CONCLUSIONS}

I began this exploration by asking about the relevance and salience of a characterization of mathematics as "the secret weapon of cultural imperialism" (Bishop, 1990). Having now looked at several aspects of arithmetic, mathematics and accounting in Western Europe and the Andes during the period leading up to and a century or so beyond the fateful encounter between Pizarro and Atahualpa in Cajamarca in 1532, we return to ask: In what sense was mathematics linked to state power and governmental legitimacy in this historical conjuncture? I argue that much as critical historians writing near the end of the last century found in terms of the writing of history in colonial contexts, truth in history is usually the preserve of 


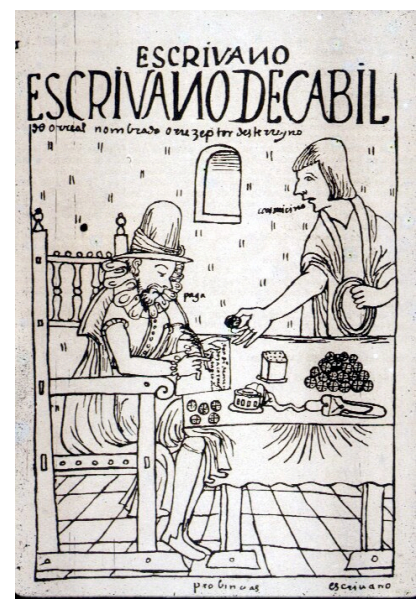

Figure 5.5. Paying tribute with a coin bearing quartered design (Guaman Poma de Ayala, 1980, p. 521_[525])

the conqueror. This is not necessarily because the conqueror knows what is, in fact, true; rather, it is because the conqueror possesses the power to speak, to produce conventionalized written accounts, and to represent and establish the rules of globalized state craft. This is the case not only in terms of narrating and writing the events of history and explaining their causes, but also in taking the measure of the world and accounting for those measurements - geographic, demographic, economic and so on - for as long as the dominant group holds power.

Power and the exercise of authority take many forms. In its most extreme and, paradoxically, weakest form, power is maintained by force. As Foucault has shown more clearly than any recent political theorist, the most effective species of power is that which takes shape as individuals and groups become complicit with and participate in institutions of the state, such as in censuses, regulatory and corrective institutions, and accounting. What is the place of mathematics in this Foucauldian, 'genealogical' conception of power and authority? I think that here we must return to the question of the certainty of mathematics, and of how that certainty relates to truth and, ultimately, to power. I suggest that the critical observation on these matters for our purposes here is that mathematics may be made to serve, although it itself is not responsible for giving rise to, regimes of power. A "regime of power" may be a particular method of bookkeeping, an accounting procedure, or a state militia.

\section{NOTES}

${ }^{1}$ According to my own inventory, there are some $850+/$ - khipu samples in museums and private collections in Europe, North America and South America. While many samples are too fragile to permit study, almost 450 samples have been closely studied to date. Observations may be viewed at http://khipukamayuq.fas.harvard.edu/ and http://instruct1.cit.cornell.edu/resear4ch/quipu ascher/. 
${ }^{2}$ For general works on khipu structures and recording principles, see Arellano, 1999; Ascher \& Ascher, 1997; Conklin, 2002; Radicati di Primeglio, 2006; Urton, 1994; 2003.

${ }^{3}$ Approximately one-third of khipu studied to date do not have knots tied in (decimal-based) tiered arrangements. I have referred to these as 'anomalous khipu' and have suggested that their contents may be more narrative than statistical in nature (Urton, 2003).

${ }^{4}$ I summarize here from a range of my studies. Readers find more detailed information in Urton, 2006, 2007 , and 2009

${ }^{5}$ Guevara-Gil and Salomon (1994) have discussed what were similar procedures, and results, in the censuses undertaken by Spanish visitadores (administrative 'visitors') who were responsible for counting, classifying and (re-)organizing local populations in the early colonial Andes.

${ }^{6}$ The Khipu Database project (KDB), located in the Department of Anthropology, Harvard University, is described fully on the project website $<$ http://khipukamayuq.fas.harvard.edu/ $>$. I gratefully acknowledge the following research grants from the National Science Foundation, which made the creation of the KDB possible: \#SBR-9221737, BCS-0228038, and BCS-0408324. Thanks also to Carrie J. Brezine, who served as Khipu Database Manager from 2002 to 2005.

${ }^{7}$ It is interesting to note that in early Chinese bookkeeping, red rods signified positive numbers while black rods were used for negative numbers. As Boyer noted, "[f]or commercial purposes, red rods were used to record what others owed to you and black rods recorded what you owed to others" (cited in Peters \& Emery, 1978, p. 425).

${ }^{8}$ Three articles published in the $1960 \mathrm{~s}-70$ s by economists and accounting historians contain a lively debate not only about whether or not the khipus contained double-entry bookkeeping, but about the claim made by one of the disputants (Jacobsen) to the effect that the Inkas may in fact have invented the technique (Buckmaster, 1974; Forrester, 1968; Jacobsen, 1964). There is not space here to review the arguments made in these three articles. Suffice it to say that, while interesting for historical purposes, these articles are all poorly informed about the nature of the khipus, about what the Spanish documents say about their use, as well as about Inka political and economic organisations.

${ }^{9}$ The khipus were declared idolatrous objects and their use was severely proscribed by the Third Council of Lima, in 1583 (Vargas Ugarte,1959). However, the khipus continued to be used for local recordkeeping purposes - in some cases down to the present day (see Mackey, 1970; Salomon, 2004).

${ }^{10}$ See the fascinating study by Salomon (1991) of one of the few references we have in the colonial literature to the engagement with coinage (la moneda de cuatro reales) by a native Andean during the colonial period. Salomon argues that the story, which appears in a well-known manuscript from Huarochirí (Salomon \& Urioste, 1991), is concerned with the internal conflicts of a man due to the competing religious sentiments he experiences over loyalty to a local deity (huaca) and the Christian deity. The narrative plays on the precise symbolism of images, as well as the lettering, on a quartered Spanish coin.

\section{REFERENCES}

Arellano, C. (2002). Quipu y tocapu: Sistemas de comunicación incas. In F. Pease (Ed.), Los Incas: Arte y simbolos (pp. 215-261). Lima: Banco de Crédito del Perú.

Ascher, M \& Ascher, R. (1997). Mathematics of the Incas: Code of the quipus. New York: Dover.

Bishop, A. J. (1990). Western mathematics: The secret weapon of cultural imperialism. Race and Class, 32(2), 51-65.

Buckmaster, D. (1974). The Incan quipu and the Jacobsen hypothesis. Journal of Accounting Research, 12(1), 178-181.

Carruthers, B. G., \& Espeland, W. N. (1991). Accounting for rationality: Double-entry bookkeeping and the rhetoric of economic rationality. The Journal of American Sociology, 97, 31-69.

Cieza de León, P. de. (1967). El señorio de los Incas. Lima: Instituto de Estudios Peruanos.

Conklin, W. J. (2002). A khipu information string theory. In J. Quilter \& G. Urton (Eds.), Narrative threads: Accounting and recounting in Andean khipu (pp. 53-86). Austin: University of Texas Press. 


\section{MATHEMATICS AND ACCOUNTING IN THE ANDES}

Craig, F. Jr. (1989). Coinage of the viceroyalty of el Perú. In W. I. Bischoff (Ed.), The coinage of el Perú. New York: The American Numismatic Society.

Forrester, D. A. R. (1968). The Incan contribution to double-entry accounting. Journal of Accounting Research, 6(2), 283.

Guevara-Gil, A. \& Salomon, F. (1994). A "personal visit": Colonial political ritual and the making of Indians in the Andes. Colonial Latin American review, 3(1-2), 3-36.

Hemming, J. (1970). The conquest of the Incas. New York: Harcourt Brace Jovanovich.

Jacobsen, L. E. (1964). The ancient Inca empire of Peru and the double entry accounting concept. Journal of Accounting Research, 2(2), 221-28.

Julien, C. (1988). How Inca decimal administration worked. Ethnohistory, 35(3), 257-79.

Loza, C. B. (1998). Du bon usage des quipus face a l'administration coloniale Espagnole, 1553-1599. Population, 53(2), 139-60.

Mackey, C. (1970). Knot records of ancient and modern Peru. Unpublished Ph.D. dissertation, University of California, Berkeley. Ann Arbor: University Microfilms.

Miller, P. (1990). On the interrelations between accounting and the state. Accounting, Organizations and Society, 15(4), 315-38.

Murra, J. V. (1982). The mit'a obligations of ethnic groups to the Inka state. In G. A. Collier, R. Renato \& J. D. Wirth (Eds.), The Inca and Aztec states, 1400-1800: Anthropology and history (pp. 237-62). New York: Academic Press.

Murúa, Fray M. de. (2001). Historia general del Perú. M. B. Gaibrois (Ed.). Madrid: Dastin Historia.

Murúa, Fray M. de. (2004). Códice Murúa - historia y genealogía de los reyes Incas del Perú del Padre Mercenario Fray Martín de Murúa (Códice Galvin). J. Ossio (Ed.). Madrid: Testimonio Compañía Editorial, S.A.

Pärssinen, M. (1992). Tawantinsuyu:The Inca state and its political organization. Helsinki: Societas Historica Finlandiae.

Pärssinen, M. \& Kiviharju, J. (Eds.). (2004). Textos Andinos: Corpus de textos khipu incaicos y coloniales (Vol. I). Madrid: Instituto Iberoamericano de Finlandia and Universidad Complutense de Madrid.

Peters, R. M., \& Emery, D. R. (1978). The role of negative numbers in the development of double entry bookkeeping. Journal of accounting research, 16(2), 424-426.

Platt, T. (2002). "Without deceit or lies": Variable chinu readings during a sixteenth-century tributerestitution trial. In J. Quilter \& G. Urton (Eds.), Narrative threads: accounting and recounting in Andean khipu, (pp. 225-65). Austin: University of Texas Press.

Radicati di Primeglio, C. (2006). Estudios sobre los quipus. (G. Utron Trans., \& Ed.). Lima: Fondo Editorial Universidad Nacional Mayor de San Marcos.

Salomon, F. (1991).La moneda que a don Cristóbal se le cayó: El dinero como elemento simbólico en el texto Runa Yndio Niscap Machoncuna. In S. Moreno \& F. Salomon (Eds.), Reproducción y transformación de las sociedades andinas, siglos XVI-XX, (pp. 481-586). Quito: Ediciones ABYAYALA.

Salomon, F. (2004). The cord keepers: Khipus and cultural life in a Peruvian village. Durham and London: Duke University Press.

Salomon, F. \& Urioste, J. L. (1991). The Huarochiri manuscript: A testament of ancient and colonial Andean religion. Austin: University of Texas Press.

Spalding, K. (1973). Kurakas and commerce: A chapter in the evolution of Andean society. The Hispanic American Historical Review, 53(4), 581-99.

Stern, S. J. (1986). Peru's Indian peoples and the challenge of Spanish conquest. Madison, WI: University of Wisconsin Press.

Swetz, F. J. (1989). Capitalism and arithmetic: The new math of the $15^{\text {th }}$ century. La Salle, IL: Open Court.

Urton, G. (1994). A new twist in an old yarn: Variation in knot directionality in the Inka khipus. Baessler-archiv Neue Folge, 42, 271-305. 


\section{URTON}

Urton, G. (2003). Signs of the Inka khipu: Binary coding in the Andean knotted-string records. Austin: University of Texas Press.

Urton, G. (2005). Khipu archives: Duplicate accounts and identity labels in the Inka knotted string records. Latin American Antiquity, 16(2), 147-67.

Urton, G. (2006). Censos registrados en cordeles con 'amarres': Padrones poblacionales pre-hispánicos y coloniales tempranos en los khipu Inka. Revista Andina, 42, 153-96.

Urton, G. \& Brezine, C. (2005). Khipu accounting in ancient Peru. Science, 309, 1065-67.

Vargas Ugarte, R. (1959). Historia de la iglesia en el Perú (1570-1640) (Vol. 2). Burgos, Spain: Aldecoa. 